\title{
Diuron metabolites act as endocrine disruptors and alter aggressive behavior in Nile tilapia (Oreochromis niloticus)
}

\author{
Camila Nomura Pereira Boscolo ${ }^{a}$, Thiago Scremin Boscolo Pereira ${ }^{\text {b }}$, \\ Isabela Gertrudes Batalhão ${ }^{a}$, Priscila Leocadia Rosa Dourado ${ }^{a}$, Daniel Schlenk ${ }^{c}$, \\ Eduardo Alves de Almeida d, * \\ ${ }^{a}$ UNESP - Sao Paulo State University, Department of Chemistry and Environmental Sciences, São Paulo, Brazil \\ ${ }^{\mathrm{b}}$ Faculdade de Medicina - Faceres, São José do Rio Preto, São Paulo, Brazil \\ ${ }^{\mathrm{c}}$ Department of Environmental Sciences, University of California, Riverside, USA \\ ${ }^{\mathrm{d}}$ FURB Fundação Universidade Regional de Blumenau, Department of Natural Sciences, Blumenau, Santa Catarina, Brazil
}

\section{H I G H L I G H T S}

- Nile tilapia were exposed (10 days; $100 \mathrm{ng} \mathrm{L}^{-1}$ ) to diuron and two diuron metabolites.

- Diuron metabolites increase levels of cortisol and decrease testosterone in plasma.

- Diuron metabolites decrease brain Dopamine levels and aggressiveness in Nile tilapia.

\section{A R T I C L E I N F O}

\section{Article history:}

Received 12 June 2017

Received in revised form

6 September 2017

Accepted 1 October 2017

Available online 3 October 2017

Handling Editor: Jim Lazorchak

\section{Keywords:}

Behavior

Brain neurotransmitter

Herbicides

Hormones

\begin{abstract}
A B S T R A C T
Diuron and its biodegradation metabolites were recently reported to cause alterations in plasma steroid hormone concentrations with subsequent impacts on reproductive development in fish. Since steroid hormone biosynthesis is regulated through neurotransmission of the central nervous system (CNS), studies were conducted to determine whether neurotransmitters that control hormone biosynthesis could be affected after diuron and diuron metabolites treatment. As the same neurotransmitters and steroid hormones regulate behavioral outcomes, aggression was also evaluated in male Nile tilapia (Oreochromis niloticus). Male tilapias were exposed for 10 days to waterborne diuron and the metabolites 3,4-dichloroaniline (DCA), 3,4-dichlorophenyl-N-methylurea (DCPMU), at nominal concentrations of $100 \mathrm{ng} \mathrm{L}^{-1}$. In contrast to Diuron, DCA and DCPMU significantly diminished plasma testosterone concentrations (39.4\% and $36.8 \%$, respectively) and reduced dopamine levels in the brain $(47.1 \%$ and $44.2 \%$, respectively). In addition, concentrations of the stress steroid, cortisol were increased after DCA (71.0\%) and DCPMU (57.8-\%) exposure. A significant decrease in aggressive behavior was also observed in animals treated with the metabolites DCA (50.9\%) and DCPMU (68.8\%). These results indicate that biotransformation of diuron to active metabolites alter signaling pathways of the CNS which may impact androgen and the stress response as well as behavior necessary for social dominance, growth, and reproduction.
\end{abstract}

๑) 2017 Elsevier Ltd. All rights reserved.

\section{Introduction}

Diuron (3-[3,4-dichlorophenyl]-1,1-dimethyl urea) is a substituted urea herbicide widely used for weed control in various crops. In addition to having potential toxicity for non-target species

\footnotetext{
* Corresponding author.

E-mail address: edualves1976@hotmail.com (E.A. de Almeida).
}

(Nebeker and Schuytema, 1998), diuron can be degraded by soil microbiota (half-life between 20 and 120 days in water) into other compounds such as 3,4-dichloroaniline (DCA), 3,4dichlorophenylurea (DCPU) and 3,4-dichlorophenyl-N-methylurea (DCPMU) (Giacomazzi and Cochet, 2004; Tixier et al., 2002). Diuron and its metabolites have been observed in soils (Field et al., 2003) and can reach rivers and lakes through run-off and leaching (Gooddy et al., 2002), allowing exposure to many aquatic organisms, such as fish (Nebeker and Schuytema, 1998). 
Previous studies in our laboratory showed that diuron and its metabolites caused estrogenic activity (Felício et al., 2016; Pereira et al., 2016) and anti-androgenic activity in fish (Pereira et al., 2015). Neuroendocrine factors play a significant role in fish behavior (Scott and Sloman, 2004). According to Johnsson et al. (2005), androgens positively modulate aggression in fish, and aggressive interactions are followed by elevation of androgen levels (Oliveira et al., 2001; Chang et al., 2012). In addition, the glucocorticoid steroid cortisol has also been shown to be involved in behavioral responses to stressful conditions, particular within high density social situations (Oliveira and Gonçalves, 2008; Boscolo et al., 2011).

Steroid hormone concentrations are regulated through the central nervous system by the neurotransmitters dopamine (3,4dihydroxyphenethylamine; DA) (Randall and Perry, 1992) and serotonin (5-hydroxytryptamine; 5-HT) (Rubinow et al., 1998; Rysz et al., 2016; Hansen et al., 2017). DA is also involved in behavioral activation, motivated behavior, and reward processing (Ikemoto and Panksepp, 1999), while 5-HT has the opposite effect of decreasing aggressiveness (Nelson and Chiavegatto, 2001; Trainor et al., 2017). Therefore, any change in these neurotransmitters or steroid hormone concentrations due to pollutant exposure could alter behavior in fish (e.g. De Boeck et al., 1995; Smith et al., 1995). Various endocrine active chemicals have been found to affect behavioral processes, including reproductive behavior in Poecilia reticulata (Tomkins et al., 2016), anti-predatory responses in Carassius auratus (Saglio and Trijasse, 1998), as well cognitive capacity in rat (Roegge et al., 2000). However, the relationships between signaling, hormones and behavior are unclear.

Thus, given the important role of glucocorticoid and sex steroid hormones in the regulation of behavior in fish, the purpose of the present study was to evaluate the relationship between the antiandrogenic effects of diuron and its metabolites with neurological function through the measurement of aggression behavior in Nile tilapia (Oreochromis niloticus). Male Nile tilapia are excellent model organisms to explore the effects of environmental contaminants on aggressive behavior (Boscolo et al., 2011; Barreto et al., 2015). In general, cichlid fishes, such as Nile tilapia, have defined dominance hierarchy through aggressive interactions (Lowe-McConnell, 1958). In these interactions the animals fight aggressively to define the social hierarchy (e.g Enquist and Jakobsson, 1986; Turner and Huntingford, 1986). According to Oliveira and Gonçalves (2008) dominant fish have higher levels of androgens than submissive, and this change in hormone levels reinforces dominance (e.g. Wingfield et al., 1990; Parikh et al., 2006). Since diuron metabolites caused anti-androgenic effects in O. niloticus (Pereira et al., 2015; Felício et al., 2016), and cortisol, androgens, DA and 5HT are important modulators of aggressive behavior in fish, we hypothesized that the anti-androgenic effects of diuron metabolites in Nile tilapia cause alterations in aggressive behavior, which will be associated with concomitant alterations in androgen (decrease), cortisol (increase) and brain neurotransmitter levels (DA and 5HTincrease).

\section{Methods}

\subsection{Animals and housing}

Adult males (O. niloticus) of similar size (Table 1 ) were randomly selected from a stock culture maintained at the São Paulo State University (UNESP), São José do Rio Preto, Brazil. Fish were kept in $500 \mathrm{~L}$ indoor stock-tanks with dechlorinated well water (ca. 1 fish $5 \mathrm{~L}^{-1}$ ) during 30 days for acclimation before experiment began (e.g. Boscolo et al., 2011). Food (commercial pellets for tropical fish, 32\% crude protein - Guabi-Pirá/Brazil) was provided twice a day to
Table 1

Mean $\left( \pm\right.$ SD) of the measured concentrations of each compound in water, $\mathrm{pH}, \mathrm{NH}_{3}$ standard length and body weight from Nile tilapia males exposed to diuron and its metabolites during 10 days $(\mathrm{N}=12)$.

\begin{tabular}{lllll}
\hline & Control & Diuron & DCA & DCPMU \\
\hline $\begin{array}{c}\text { Measured conc. } \\
\quad\left(\text { ng L L }^{-1}\right)\end{array}$ & $<$ LD & $86.6 \pm 35.5$ & $80.8 \pm 23.1$ & $64.5 \pm 13.5$ \\
$\mathrm{pH}$ & $7.6 \pm 0.2$ & $7.7 \pm 0.3$ & $7.7 \pm 0.3$ & $7.6 \pm 0.2$ \\
$\mathrm{NH}_{3}\left(\mathrm{mg} \mathrm{L}^{-1}\right)$ & $0.85 \pm 0.25$ & $0.85 \pm 0.15$ & $0.80 \pm 0.13$ & $0.74 \pm 0.10$ \\
Body length (cm) & $11.03 \pm 0.42$ & $11.75 \pm 0.78$ & $11.76 \pm 0.84$ & $11.00 \pm 0.97$ \\
Body weight $(\mathrm{g})$ & $53.13 \pm 18.41$ & $53.81 \pm 8.87$ & $56.39 \pm 13.40$ & $48.10 \pm 12.36$ \\
\hline
\end{tabular}

$\mathrm{LD}=$ limit of detection.

satiation. External biological filters ( $400 \mathrm{~L} / \mathrm{h}$ ) and constant aeration ensured water quality. Water temperature was kept at $27 \pm 1{ }^{\circ} \mathrm{C}$ and photoperiod was $12 \mathrm{~L}: 12 \mathrm{D}$. The tanks were siphoned weekly to remove leftover food and feces. This study was conducted in agreement with the precepts of National Council for the Control of Animal Experimentation (CONCEA) and was approved by the Committee for Ethics on Using Animal (CEUA), UNESP, São José do Rio Preto, SP, Brazil e permit 0715/2013.

\subsection{Exposures}

After the acclimation period, the animals were divided into four groups of 12 fish $(\mathrm{N}=12)$, with each fish individually placed in one of 48 aquariums containing $17 \mathrm{~L}$ of dechlorinated tap water (one fish per aquarium). The groups were then exposed for 10 days to one of the following treatments (nominal concentrations): Diuron (100 ng L ${ }^{-1}$ ), DCPMU (100 ng.. $\left.\mathrm{L}^{-1}\right)$, DCA (100 ng L $\left.{ }^{-1}\right)$, and one group that were not exposed to any compound (control group). After the exposure period, animals were collected for the evaluation of aggressive behavior, hormone levels and brain neurotransmitter levels. Selection of the exposure period was based on previous experiments that showed that exposure to these same compounds during 7-25 days are sufficient to induce hormonal changes in Nile tilapias (Felício et al., 2016; Pereira et al., 2015). Selection of the concentration of the compounds was based on the mean values found in contaminated aquatic environments (up to $200 \mathrm{ng} \mathrm{L}^{-1}$ ) (Köck-Schulmeyer et al., 2013; Masiá et al., 2015; Schlenk et al., 2012) and also based on the European Union legislation for unregulated herbicides, such as diuron, which determines $100 \mathrm{ng} \mathrm{L}^{-1}$ as the acceptable limit for individual herbicides in water (SanchisMallols et al., 1998). All chemicals (>98\% purity, Sigma-Aldrich Chemical; St. Louis, MO, USA) were dissolved in a stock solution of $1 \mathrm{~mL}$ of acetone and then added $(100 \mu \mathrm{l})$ into the water of experimental aquariums. Control groups also received the same volume of acetone (without contaminants) to avoid interpretation of the results due to solvent effects.

During the experimental period fish were fed with ration for tropical fish (Guabi-Pirá/Brazil) corresponding to $3 \%$ of biomass, offered at 9:00 $\mathrm{h}$ and 16:00 h. The photoperiod was $12 \mathrm{~L}: 12 \mathrm{D}$ (7:00-19:00 $\mathrm{h}$ ) and water mean temperature was $26.7 \pm 1.5^{\circ} \mathrm{C}$, and $\mathrm{NH}_{3}$ was monitored during the experiment (Table 1). Dissolved oxygen was maintained at $>5 \mathrm{mg} \mathrm{L}^{-1}$ throughout the experiment, and water $\mathrm{pH}$ was $7.4 \pm 0.4$.

To measure and confirm the diuron, DCA and DCPMU concentrations, water samples taken before the addition of fish into the aquarium were analyzed using High Performance Liquid Chromatography (HPLC) (Pereira et al., 2015, 2016). Measured chemical values are given in Table 1 . The minimum detection concentration was $10 \mathrm{ng} \mathrm{L}^{-1}$. Water containing the respective compounds was changed every five days by static renewal to maintain water quality and compound concentrations. However, it should be noted that 
concentrations of diuron, DCA and DCPMU after 5 days were not checked. According to US-EPA, diuron has limited degradation by hydrolysis in water at $25^{\circ} \mathrm{C}$, and has a half-life of 20-90 days by aerobic biodegradation. DCA is considered even more stable than diuron (1240-1330 days), and data for DCPMU hydrolysis in water are inexistent. However DCPMU half-life by aerobic biodegradation in soils is between 40 and 120 days. Therefore, significant changes in diuron, DCA and DCPMU concentrations due to degradation in water was not expected to occur during 5 days, especially considering that microorganisms were absent at relevant amounts in the experimental aquariums. Nevertheless, concentrations could be changed due to fish absorption. In a pilot study (unpublished results), Nile tilapias that were exposed to diuron at $1 \mathrm{mg} \mathrm{L}^{-1}$ presented $116.03( \pm 109.62), 525.02( \pm 93.87), 889.27( \pm 97.49)$ and $1197.17( \pm 105.47) \mathrm{ng} \mathrm{mL}^{-1}$ of diuron in plasma, after $0.5,1.0,3.0$ and $8.0 \mathrm{~h}$ of exposure, respectively. Although the kinetics of DCA and DCPMU absorption were not studied, it is expected that these compounds were also effectively absorbed by fish during 5 days of exposure, which may have caused a decrease in water concentrations during the duration of exposure.

\subsection{Behavior trials}

The effect of exposure to diuron and its metabolites on aggressive behavior was investigated matching two animals that were exposed to the same contaminants. The interaction took place on the 11th day in separate aquarium containing the same contaminant. This procedure was performed to exclude the effects of previous residence (e.g. Chellappa et al., 1999). To identify the animals during the aggressive interactions Visual Implanted Elastomer (VIE) ties were used (Barreto et al., 2015). The animals were matched for 20 min under these experimental conditions where aggressive interactions were video-recorded and evaluated by the frequency and types of behavior. Aggressive interactions was the same described by Barreto et al. (2015) for Nile tilapia, such as threat, mouth fighting, nipping, lateral fighting, undulation and chase. The sum of all aggressive interactions types (total fight) was recorded.

\subsection{Hormonal analyses}

The animals were anesthetized by immersion in water containing benzocaine $\left(9 \mathrm{mg} \mathrm{L}^{-1}\right)$ for blood collection and biometry immediately after behavior trials. Blood was collected by puncturing the caudal vein with hypodermic needles and heparinized syringes (Liquemine, Roche, Rio de Janeiro, RJ, Brazil). The capture management, anesthesia and blood collection was performed in less than $1 \mathrm{~min}$ to avoid interference from the stress manipulation (e.g. Pottinger, 2008). The blood was centrifuged at $3000 \mathrm{~g}$ for 10 min and plasma was separated and frozen at $-80{ }^{\circ} \mathrm{C}$ for subsequent hormonal analyses. The concentrations of the hormones cortisol, testosterone ( $\mathrm{T}$ ) and ketotestosterone (KT) were determined using Enzyme Linked Immunosorbent Assay (ELISA) with commercial kits (IBL- Immuno Biological Laboratories, Hamburg, Germany to cortisol and testosterone and Cayman Chemical Company, MI, USA for KT). The acceptable limit for CV inter-assay was $\leq 20.0 \%$ (Brown et al., 2004).

\subsection{Neurotransmitter analyses}

Following blood sampling, the fish was killed by decapitation, and the brain was rapidly removed and frozen in liquid nitrogen and stored at $-80^{\circ} \mathrm{C}$. Brain tissue samples were weighed and homogenized using a homogenizer in ice-cold 0.1-M perchloric with cysteine $3 \mathrm{mM}$. The final homogenate was centrifuged $(10,000 \mathrm{~g}$ for $10 \mathrm{~min}$ at $4{ }^{\circ} \mathrm{C}$ ) and supernatant was filtered through a $0.22-\mu \mathrm{m}$ filter. After filtered, $10 \mu \mathrm{l}$ of the filtrate was injected into an HPLC system for estimation of dopamine and serotonin. The monoamines were monitored with a fluorescence detector (Shimadzu, model RF20 A) set with wavelength of $279 \mathrm{~nm}$ of excitation and $320 \mathrm{~nm}$ of emission. The HPLC system (Shimadzu Corporation, Kyoto, Japan) consisted of one CBM20A communication bus module, two LC20AD-XR pumps, one DGU20A3 R degassing unit, one SIL20ACXR autosampler, and one CTO20AR column oven. The components were separated in an ACE C18 column $(250 \times 4.6 \mathrm{~mm}, 5 \mu \mathrm{m})$. The mobile phase (acetic acid $12 \mathrm{mM}, \mathrm{Na}_{2}$-EDTA $0.26 \mathrm{mM}$, with $10 \%$ methanol) was pumped at an isocratic flow of $1 \mathrm{~mL} \mathrm{~min}^{-1}$. Chromatogram monitoring and peak identification and quantification were performed using the LAB Solutions 5.71 software (Shimadzu Corporation). The calculations were based on a calibration curve previously constructed and prepared according to same procedure described above for the samples using authentic standards (>98\% purity, Sigma-Aldrich Chemical; St. Louis, MO, USA). The results were expressed in pg. $\mathrm{g}^{-1}$.

\subsection{Statistical analysis}

The outliers were identified by mean \pm 2 SD and these values were replaced by the mean (as recommended by Cousineau et al., 2010). Data normality was evaluated using the Cramer von e Mises test, and data homoscedasticity was tested by Levene's test, with a significance level of 0.05. One-way ANOVA General Linear Models (GLM) was used to evaluate aggressive interactions, steroids, serotonin and dopamine. The Fisher's Least Significant Difference (LSD) test was used in post hoc analyses and $\mathrm{P} \leq 0.05$ was used to infer statistical significance.

\section{Results}

\subsection{Fish mortality and growth}

Mortality was not observed in any of the treatments. Differences were not observed in body length and body weight among treatments ( $\mathrm{P}=0.21$, Table 1$)$.

\subsection{Hormones levels}

Male Nile tilapia exposed to diuron metabolites for 10 days had significantly altered steroid hormone levels (Fig. 1). Cortisol plasma levels increased $(\mathrm{P}=0.02)$ only in the animals exposed to either DCA and DCPMU compared to the control (71.0 and 57.8\%, respectively) (Fig. 1 A). Testosterone plasma levels were reduced $(\mathrm{P}=0.01)$ in animals exposed to diuron metabolites DCA and (39.4\%) DCPMU (36.8\%) compared to the control group and the group exposed to diuron. (Fig. 1 B). There was no difference observed with KT plasma levels between treatments $(P=0.98)$ (Fig. 1 C).

\subsection{Aggressive interactions}

Exposure to diuron metabolites DCA and DCPMU significantly altered fish behavior ( $P=0.02$ ), decreasing the aggressive interactions by $50.9 \%$ and $68.8 \%$, respectively (Fig. 2). In contrast, diuron did not cause behavior alterations.

\subsection{Brain neurotransmitters}

Male Nile tilapia exposed to DCA and DCPMU for 10 days presented decreased $(P=0.02)$ dopamine levels $(47.1 \%$ and $44.2 \%$, respectively) compared to the control (Fig. 3 A). Exposure to diuron did not alter dopamine levels compared to the control group and 


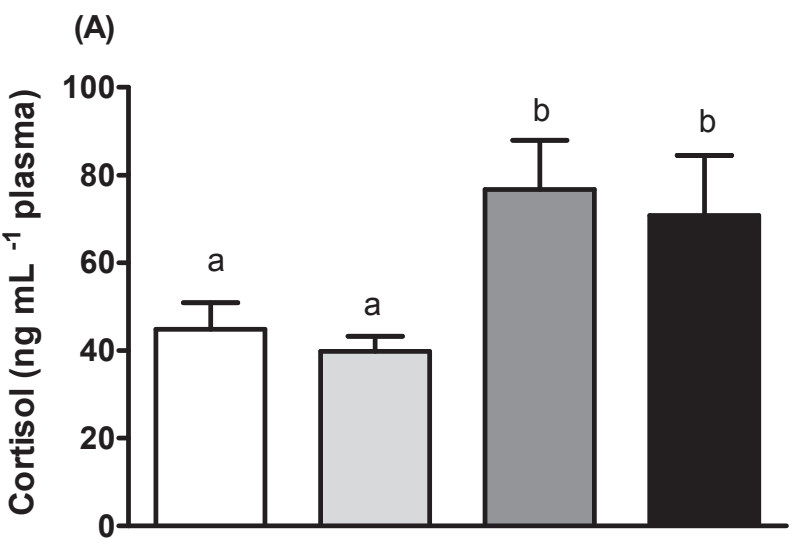

(B)

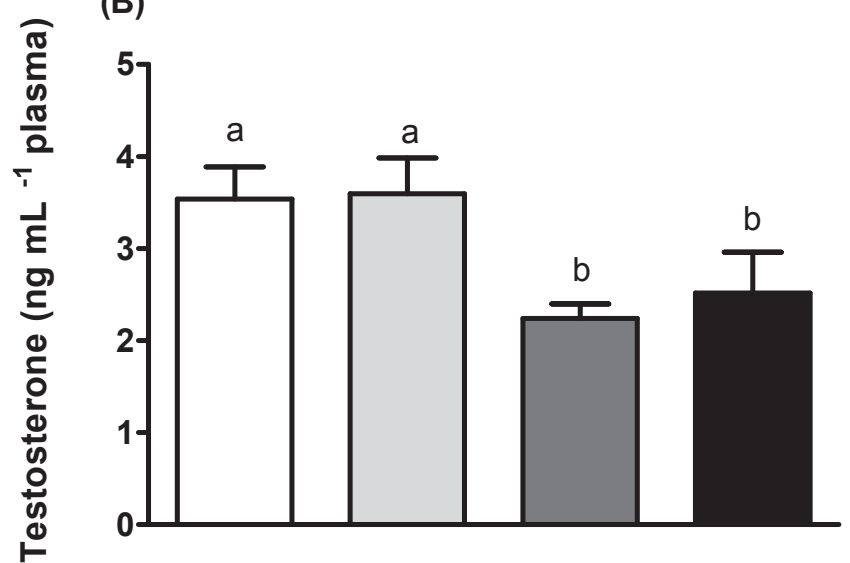

(C)

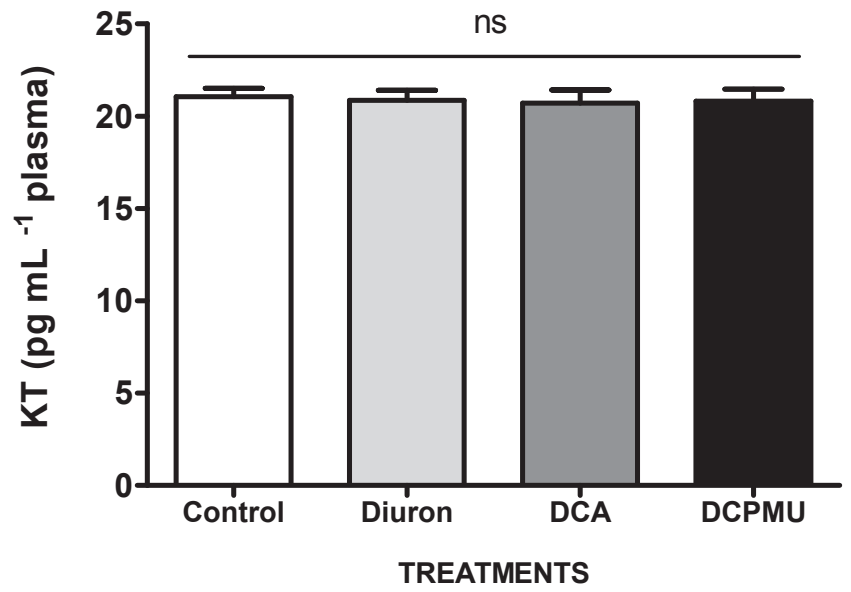

Fig. 1. Plasma concentrations of (A) cortisol, (B) testosterone and (C) 11ketotestosterone of Nile tilapia males exposed to diuron and its metabolites for 10 days. Each value represents the mean $\pm \mathrm{SE}(\mathrm{N}=12)$. Different letters indicate significant differences among treatments (ANOVA, Fisher's LSD test, $\mathrm{P}<0.05$ ).

there were no differences $(\mathrm{P}=0.30)$ in brain serotonin levels (5HT) between diuron or diuron metabolite treatments (Fig. $3 \mathrm{~B}$ ).

\section{Discussion}

Studies integrating neuroendocrine effects of pesticides on fish with alterations in aggressive behavior are limited, despite reports of alterations in social behavior (Shinn et al., 2015; Saglio and Trijasse, 1998). Aggressiveness is an important factor for cichlids during intraspecific competition for the establishment of

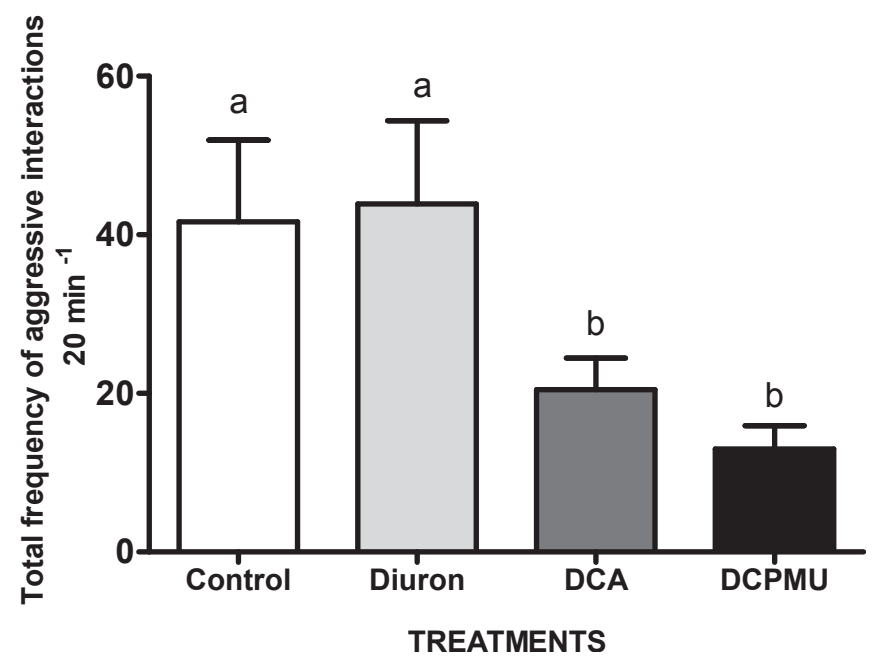

Fig. 2. Total aggressive interaction of Nile tilapia males after exposure to diuron and its metabolites for 10 days. Each value represents the mean average of 12 animals + SE. Different letters indicate significant differences among treatments (ANOVA, Fisher's LSD test, $\mathrm{P}<0.05$ ).

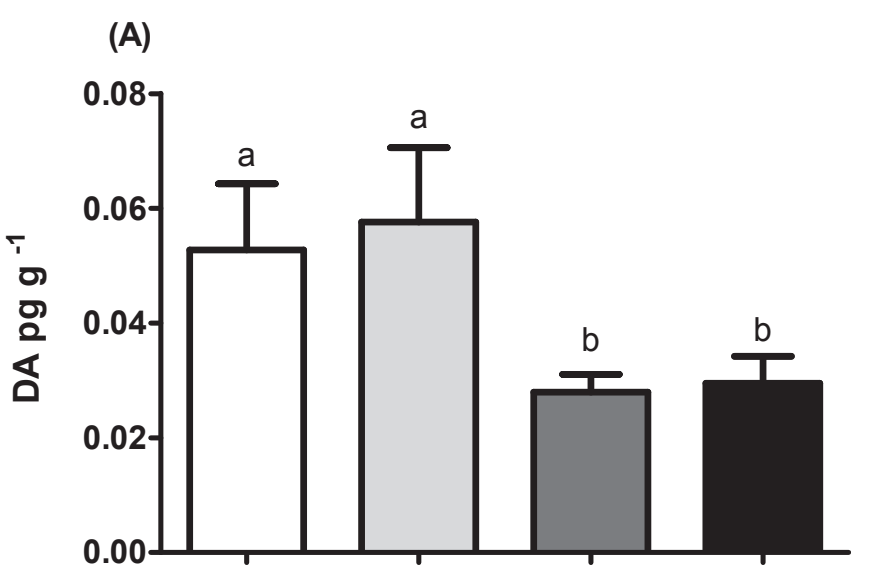

(B)

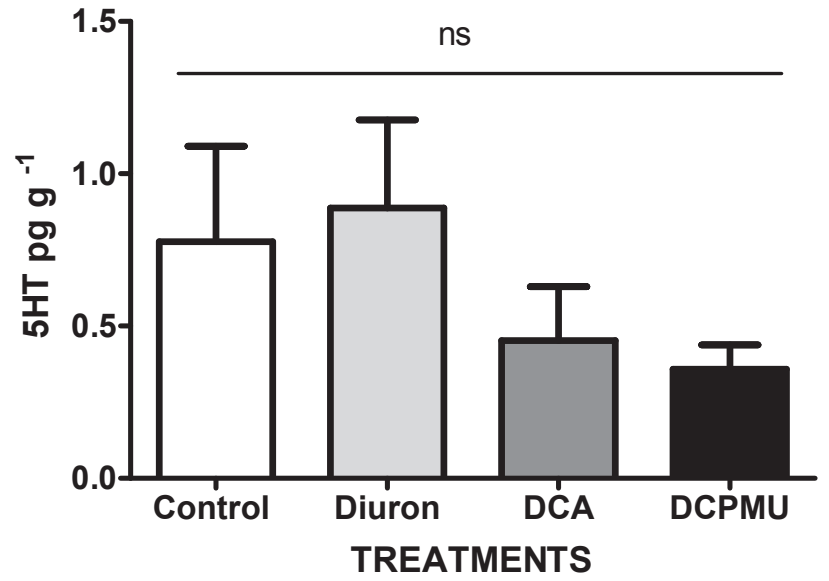

Fig. 3. Concentration of (A) dopamine, (B) serotonin in brain of Nile tilapia males exposed to diuron and its metabolites for 10 days. Each value represents the mean average of 12 animals + SE. Different letters indicate significant differences among treatments (ANOVA, Fisher's LSD test, $\mathrm{P}<0.05$ ). a.

dominance hierarchy, which ensures resources for optimal growth (Enquist and Jakobsson, 1986; Turner and Huntingford, 1986; 
Boscolo et al., 2011). Therefore, alterations in the aggressive interaction due to the presence of toxicants may lead to failure in maintaining a territory and in ensuring adequate conditions for survival (i.e. food and shelter) and reproduction (Triebskorn et al., 1997).

Increase in plasma cortisol levels is a common response of the hypothalamus-pituitary-interrenal axis (HPI) in male Nile tilapias to different kinds of stress (Wendelaar Bonga, 1997), including pollutant exposure (Scott and Sloman, 2004; Firat and Kargin, 2010; Firat et al., 2011; Koakoski et al., 2013). Fish that are incapable of triggering a normal cortisol response to stress are likely to have a reduced ability to respond to the continuous challenges imposed on their homeostatic systems during stressed conditions, possibly due to the innefficiency of glucose recruitment (Brodeur et al., 1997). In this study, fish exposed to diuron metabolites, but not to diuron, presented increased cortisol levels when compared to the control group, after being placed in presence of other males, suggesting a stressed condition. However, although having elevated cortisol, fish that were exposed to diuron metabolites presented reduced aggressive interactions. These results demonstrate that the ability to produce cortisol in response to a confrontation with another male through the HPI axis in the interrenal tissue was preserved after exposure to diuron metabolites. Nevertheless diuron metabolites impaired the mechanisms leading to aggressive response of the fish, possibly by altering the production of neurotransmitters related to the modulation of aggressive behavior and also as a consequence of previously observed anti-androgenic effect of these compounds (Pereira et al., 2016).

Considering that $\mathrm{T}$ and $11 \mathrm{KT}$ stimulates aggressive behavior in male vertebrates, concentrations of androgens involved in behavioral responses were also evaluated. Previous studies showed that diuron at $200 \mathrm{ng} \mathrm{L}^{-1}$ reduced T, and that diuron and its metabolites at same concentration reduced $\mathrm{T}$ and $11 \mathrm{KT}$ after 25 days of exposure in Nile tilapia (Pereira et al., 2015). However in the current study, only the metabolites reduced $\mathrm{T}$. Reasons for the differences may be related to the duration of exposure (10 days) and to the concentration used ( $100 \mathrm{ng} \mathrm{L}^{-1}$ ), which were not enough to cause the same effect as observed by Pereira et al. (2016). In a previous study, we demonstrated that Nile tilapia is able to metabolize diuron and its metabolites (Felício et al., 2016), thus it can be also supposed that Nile tilapias metabolized these compounds more effectively at lower concentrations, also contributing to the lack of effects on $11 \mathrm{KT}$.

The study of the influence of androgens on aggression can be traced back to the classic experiments of Arnold Berthold in 1849 (Quiring, 1944) that removed the testes of roosters interrupting the production of $\mathrm{T}$, which he suspected to be necessary for the aggressive behavior, and consequently the aggressiveness was suppressed. After replacing the glandular material in the animals, he observed the return of the aggressive behavior. Similar effects of castration and androgen replacement on fish aggressiveness have been observed, and the administration of exogenous androgens has also shown to increase aggressiveness in male teleost fish (Hirschenhauser and Oliveira, 2006; Oliveira and Gonçalves, 2008). Several studies have correlated aggressive behavior with androgens in fish species. It was shown that male intrusions into territories of established territorial males induce androgen levels to increase in the stoplight parrotfish (Sparisoma viride) (Cardwell and Liley, 1991). It was also demonstrated that the frequency of territorial interaction in fish is correlated with androgen levels in male demoiselles (Chromis dispilus) (Pankhurst and Barnett, 1993) and in the African cichlid (Astatotilapia burtoni) (Parikh et al., 2006; Alcazar et al., 2016). Thus, the decrease in T levels in Nile tilapia caused by exposure to diuron metabolites in this study may likewise contribute to the impairment of the aggressive behavior.
Biosynthesis of $\mathrm{T}$ and other sex steroids is regulated by several neurotransmitters in the brain. There are intricate and reciprocal relationships between brain DA production and $T$ levels. In adolescent male rats, $\mathrm{T}$ alters the dopaminergic system by increasing local brain dopamine synthesis and metabolism (PurvesTyson et al., 2012, 2014; Sinclair et al., 2014). To enhance T biosynthesis, DA stimulates the secretion of gonadotropinreleasing hormone (GnRH) which then signals the pituitary gland to release the luteinizing hormone ( $\mathrm{LH})$, stimulating the testes to produce T (Siris et al., 1980; Li and Pelletier, 1992). Similarly, DA also controls the release of GnRH and subsequent steroid concentrations in ansynchonist spawning fish species (Yu et al., 1991). Consequently, one would predict higher levels of DA with lower concentrations of $\mathrm{T}$. The reduced levels of DA and T suggest that diuron metabolites may be interfering with other aspects of the hypothalamic-pituitary-gonadal axis. Recent studies have suggested that $17 \mathrm{~B}$ hydroxysteroid dehydrogenase may also be impacted by diuron metabolites (Felício et al., 2016). The role of steroid biosynthesis and neuroendocrine signaling warrants further study to better understand the relationships between the HPG axis and behavior as potential targets for diuron or its metabolites.

The relatively high unionized ammonia levels recorded in water after 5 days of exposure $\left(\sim 0.8 \mathrm{mg} \mathrm{L}^{-1}\right)$ may be also contributing to the effects on brain DA concentrations. Weber et al. (2012) showed that unionized ammonia caused significant decreases in brain DA and 5HT levels in the marine fish Solea senegalensis, after 12 and $24 \mathrm{~h}$ of exposure at sublethal concentrations ( $0.28 \mathrm{mg} \mathrm{L}^{-1} ; \sim 15 \%$ of the $\mathrm{LC} 50$ value). However, the $\mathrm{NH}_{3}$ levels in this study were similar for all experimental groups, and only DA levels in those animals exposed to diuron metabolites were decreased (5HT was unchanged). Indeed, the mean LC50 value for unionized ammonia for seawater species is $1.89 \mathrm{mg} \mathrm{L}^{-1}$ (EPA, 1989; Randall and Tsui, 2002), while the value for Nile tilapia is about $7.5 \mathrm{mg} \mathrm{L}^{-1}$ (Hegazi et al., 2011), making the Nile tilapia one of the most ammonia tolerant fish species. Therefore, variations observed for DA in those fish exposed to diuron metabolites is more likely to be related to the chemical exposure.

\section{Conclusion}

In summary, the results of this study with Nile tilapia reveal that diuron metabolites at environmentally relevant concentrations reduced aggressive behavior, which was associated with impairment of the neuroendocrine system of the fish. The relationships between neuroendocrine signaling and behavior require additional study as do the ramifications of diminished aggression. Evaluation of other behaviors, particularly those involved in feeding and reproduction should provide evidence of population impacts that may reduce uncertainty and more accurately determine the potential risks associated with diuron to aquatic organisms.

\section{Acknowledgements}

The authors would like to thank the "Jovem Pesquisador"PROPe- UNESP for Scholarship. This work has the financial support of FAPESP-BIOEN Program (2011/52061-8) and CNPq (401884/ 2012-0). EAA is a recipient of a CNPq productivity fellowship (307603/2014-8). The authors disclose any potential sources of conflict of interest.

\section{References}

Alcazar, R.M., Becker, L., Hilliard, A.T., Kent, K.R., Fernald, R.D., 2016. Two types of dominant male cichlid fish: behavioral and hormonal characteristics. Biol. Open 
5 (8), 1061-1071. https://doi.org/10.1242/bio.017640.

Barreto, T.N., Boscolo, C.N.P., Gonçalves-de-Freitas, E., 2015. Homogeneously sized groups increase aggressive interaction and affect social stress in Thai strain Nile tilapia (Oreochromis niloticus). Mar. Freshw. Behav. Physiol. 48, 309-318. https://doi.org/10.1080/10236244.2015.1070478.

Boscolo, C.N.P., Morais, R.N., Gonçalves-de-Freitas, E., 2011. Same-sized fish groups increase aggressive interaction of sex-reversed males Nile tilapia GIFT strain Appl. Anim. Behav. Sci. 135, 154-159. https://doi.org/10.1016 j.applanim.2011.10.003.

Brodeur, J.C., Sherwood, G., Rasmussen, J.B., Hontela, A., 1997. Impaired cortisol secretion in yellow perch (Perca flavescens) from lakes contaminated by heavy metals: in vivo and in vitro assessment. Can. J. Aquat. Sci. 54, 2752-2758.

Brown, J., Walker, S.E., Steinmain, K., 2004. Endocrine Manual for the Reproductive Assessment of Domestic and Non-Domestics Species. Conservation and Research Center, Smithsonianı s National Zoological Park. EUA, Front Royal, Virginia, p. 69.

Cardwell, J.R., Liley, N.R., 1991. Androgen control of status in males of a wild population of stoplight parrotfish Sparisoma viride. Horm. Behav. 25, 1-18.

Chang, C., Li, C.-Y., Earley, R.L., Hsu, Y., 2012. Aggression and related behavioral traits: the impact of winning and losing and the role of hormones. Integr. Comp. Biol. 52, 801-813. https://doi.org/10.1093/icb/ics057.

Chellappa, S., Yamamoto, M.E., Cacho, M.S.R.F., Huntingford, F.A., 1999. Prior residence, body size and the dynamics of territorial disputes between male freshwater angelfish. J. Fish. Biol. 55, 1163-1170. https://doi.org/10.1111/j.1095 8649.1999.tb02067.x.

Cousineau, C., Cousineau, D., Chartier, S., 2010. Outliers detection and treatment: a review. Detección y tratamiento de valores extremos: una revisión. Int. J. Psychol. Res. 3, 58-67.

De Boeck, G., Nilsson, G.E., Elofsson, U., Vlaeminck, A., Blust, R., 1995. Brain monoamine levels and energy status in common carp (Cyprinus carpio) after exposure to sublethal levels of copper. Aquat. Toxicol. 33, 265-277. https:/ doi.org/10.1016/0166-445X(95)00022-V.

Enquist, M., Jakobsson, S., 1986. Decision making and assessment in the fighting behaviour of Nannacara anomala (Cichlidae, Pisces). Ethology 72, 143-153.

EPA, 1989. Ambient Water Quality Criteria for Ammonia (Saltwater). EPA 440/5-88 04. National Technical Information Service, Springfield VA, p. 22161.

Felício, A.A., Crago, J., Maryoung, L.A., Almeida, E.A., Schlenk, D., 2016. Effects of alkylphenols on the biotransformation of diuron and enzymes involved in the synthesis and clearance of sex steroids in juvenile male tilapia (Oreochromus mossambica). Aquat. Toxicol. 180, 345-352. https://doi.org/10.1016/ j.aquatox.2016.10.015.

Field, J.A., Reed, R.L., Sawyer, T.E., Griffith, S.M., Wigington, P.J., 2003. Diuron occurrence and distribution in soil and surface and ground water associated with grass seed production. J. Environ. Qual. 32, 171-179.

Firat, O., Cogun, H.Y., Yüzereroğlu, T.A., Gök, G., Firat, O., Kargin, F., Kötemen, Y., 2011. A comparative study on the effects of a pesticide (cypermethrin) and two metals (copper, lead) to serum biochemistry of Nile tilapia, Oreochromis niloticus. Fish. Physiol. Biochem. 37 (3), 657-666.

Firat, O., Kargin, F., 2010. Individual and combined effects of heavy metals on serum biochemistry of Nile tilapia Oreochromis niloticus. Arch. Environ. Contam. Toxicol. 58 (1), 151-157. https://doi.org/10.1007/s00244-009-9344-5.

Giacomazzi, S., Cochet, N., 2004. Environmental impact of diuron transformation: a review. Chemosphere 56, 1021-1032. https://doi.org/10.1016/j.chemosphere 2004.04.061.

Gooddy, D.C., Chilton, J., Harrison, I., 2002. A field study to assess the degradation and transport of diuron and its metabolites in a calcareous soil. Sci. Total Environ. https://doi.org/10.1016/S0048-9697(02)00079-7.

Hansen, C.H., Larsen, L.W., Sørensen, A.M., Halling-Sørensen, B., Styrishave, B., 2017. The six most widely used selective serotonin reuptake inhibitors decrease androgens and increase estrogens in the H295R cell line. Toxicol. Vitro 41, 1-11.

Hirschenhauser, K., Oliveira, R.F., 2006. Social modulation of androgens in male vertebrates: meta-analyses of the challenge hypothesis. Anim. Behav. 71, 265-277. https://doi.org/10.1016/j.anbehav.2005.04.014.

Ikemoto, S., Panksepp, J., 1999. The role of nucleus accumbens dopamine in motivated behavior: a unifying interpretation with special reference to rewardseeking. Brain Res. Brain Res. Rev. 31, 6-41.

Johnsson, J.I., Winberg, S., Sloman, K.A., 2005. Social interactions. Fish. Physiol. 24 151-196. https://doi.org/10.1016/S1546-5098(05)24005-0.

Koakoski, G., Abreu, M.S., Cruz, C., Silva, D.R., Carraschi, S.P., Kreutz, L.C., Barcellos, L.J.G., 2013. Cortisol response in Nile tilapia, Oreochromis niloticus L., following acute exposure to a glyphosate-based herbicide. Environ. Sci. 1 25-32.

Köck-Schulmeyer, M., Villagrasa, M., López de Alda, M., Céspedes-Sánchez, R., Ventura, F., Barceló, D., 2013. Occurrence and behavior of pesticides in wastewater treatment plants and their environmental impact. Sci. Total Environ. 458, 466-476. https://doi.org/10.1016/j.scitotenv.2013.04.010.

Li, S., Pelletier, G., 1992. Role of dopamine in the regulation of gonadotropinreleasing hormone in the male rat brain as studied by in situ hybridization. Endocrinology 131, 395-399.

Lowe-McConnell, R., 1958. Observation on the biology of tilapia nilotica linné in east Africa waters (Pisces: Cichlidae). Rev. Zool. Bot. Afr. 57, 129-170.

Masiá, A., Campo, J., Barceló, D., Picó, Y., 2015. Pesticide monitoring in the basin of Llobregat River (Catalonia, Spain) and comparison with historical data. Sci. Tota Environ. 503, 58-68. https://doi.org/10.1016/j.scitotenv.2014.06.095.

Nebeker, A.V., Schuytema, G., 1998. Chronic effects of the herbicide diuron on freshwater Cladocerans, amphipods, midges, minnows, worms, and snails. Arch. Environ. Contam. Toxicol. 35, 441-446.

Nelson, R.J., Chiavegatto, S., 2001. Molecular basis of aggression. Trends Neurosci. 24, 713-719. https://doi.org/10.1016/S0166-2236(00)01996-2.

Oliveira, R.F., Gonçalves, D.M., 2008. Hormones and social behaviour of teleost fish. In: Magnhagen, C., Braithwaite, V.A., Forsgren, E., Kapoor, B.G. (Eds.), Fish Behaviour. Science Publishers Inc., Enfield, N.H.

Oliveira, R.F., Lopes, M., Carneiro, L.A., Canário, A.V., 2001. Watching fights raises fish hormone levels. Nature 409, 475. https://doi.org/10.1038/35054128.

Pankhurst, N.W., Barnett, C.W., 1993. Relationship of population density, territorial interaction and plasma levels of gonadal steroids in spawning male demoiselles Chromis dispilus (pisces: pomacentridae). Gen. Comp. Endocrinol. 90 (2), $168-176$.

Parikh, V.N., Clement, T.S., Fernald, R.D., 2006. Androgen level and male social status in the African cichlid, Astatotilapia burtoni. Behav. Brain Res. 166 (2), 291-295.

Pereira, T.S.B., Boscolo, C.N.P., Silva, D.G., da Batlouni, rünig H., icardo, S.R. Almeida, Schlenk D., lves de, E.A., 2015. Anti-androgenic activities of diuron and its metabolites in male Nile tilapia (Oreochromis niloticus). Aquat. Toxicol. 164, 10-15. https://doi.org/10.1016/j.aquatox.2015.04.013.

Pereira, T.S.B., Boscolo, C.N.P. Silva, Felício, A.A., Batlouni, S.R. Schlenk, D., Almeida, E.A., 2016. Estrogenic activities of diuron metabolites in female Nile tilapia (Oreochromis niloticus). Chemosphere 146, 497-502.

Pottinger, T.G., 2008. Fish Welfare, first ed. Blackwell Publishing Ltd, UK.

Purves-Tyson, T.D., Handelsman, D.J., Double, K.L., Owens, S.J., Bustamante, S., Weickert, C.S., 2012. Testosterone regulation of sex steroid-related mRNAs and dopamine-related mRNAs in adolescent male rat substantia nigra. BMC Neurosci. 13, 95.

Purves-Tyson, T.D., Owens, S.J., Double, K.L., Desai, R., Handelsman, D.J., Weickert, C.S., 2014. Testosterone induces molecular changes in dopamine signaling pathway molecules in the adolescent male rat nigrostriatal pathway. PLOS One 9 (3), e91151.

Quiring, D.P., 1944. Transplantation of testes (by A. A. Bethold). Bull. Hist. Med. 16, 399-401.

Randall, D.J., Perry, S.F., 1992. Catecholamines. In: Randall, D.J., Hoar, W.S. (Eds.), Fish Physiology. The Cardiovascular System, Vol XIIB. Academic Press, New York, pp. $255-300$.

Randall, D.J., Tsui, T.K.N., 2002. Ammonia toxicity in fish. Mar. Poll. Bull. 45, 17-23.

Roegge, C.S., Seo, B.W., Crofton, K.M., Schantz, S.L., 2000. Gestational-lactational exposure to Aroclor 1254 impairs radial-arm maze performance in male rats. Toxicol. Sci. 57, 121-130.

Rubinow, D.R., Schmidt, PJ., Roca, C.A., 1998. Estrogen-serotonin interactions: implications for affective regulation. Biol. Psychiatry 44 (9), 839-850.

Rysz, M., Bromek, E., Haduch, A., Liskova, B., Wójcikowski, J., Daniel, W.A., 2016. The reverse role of the hypothalamic paraventricular (PVN) and arcuate (ARC) nuclei in the central serotonergic regulation of the liver cytochrome P450 isoform CYP2C11. Biochem. Pharmacol. 112, 82-89. https://doi.org/10.1016/ j.bcp.2016.04.017.

Saglio, P., Trijasse, S., 1998. Behavioral responses to atrazine and diuron in goldfish. Arch. Environ. Contam. Toxicol. 35, 484-491. https://doi.org/10.1007/ s002449900406.

Sanchis-Mallols, J.M., Sagrado, S., Medina-Hernandez, M.J., Camanas, R.M.V., BonetDomingo, E., 1998. Determination of phenylurea herbicides in drinking waters by HPLC and solid phase extraction. J. Liq. Chromatogr. Relat. Technol. 21, 869-881.

Schlenk, D., Lavado, R., Loyo-Rosales, J.E., Jones, W., Maryoung, L., Riar, N., Werner, I. Sedlak, D., 2012. Reconstitution studies of pesticides and surfactants exploring the cause of estrogenic activity observed in surface waters of the san francisco bay delta. Environ. Sci. Technol. 46, 9106-9111. https://doi.org/10.1021/ es3016759.

Scott, G.R., Sloman, K.A., 2004. The effects of environmental pollutants on complex fish behaviour: integrating behavioural and physiological indicators of toxicity. Aquat. Toxicol. 68, 369-392.

Shinn, C., Santos, M.M., Lek, S., Grenouillet, G., 2015. Behavioral response of juvenile rainbow trout exposed to an herbicide mixture. Ecotoxicol. Environ. Saf. 112, 15-21.

Sinclair, D., Purves-Tyson, T.D., Allen, K.M., Weickert, C.S., 2014. Impacts of stress and sex hormones on dopamine neurotransmission in the adolescent brain. Psychopharmacology 231, 1581-1599.

Siris, S.G. Siris, E.S., van Kammen, D.P., Docherty, J.P. Alexander, P.E., Bunney Jr., W.E., 1980. Effects of dopamine blockade on gonadotropins and testosterone in men. Am. J. Psych. 137, 211-214.

Smith, G.M., Khan, A.T., Weis, J.S., Weis, P., 1995. Behavior and brain chemistry correlates in mummichogs (Fundulus heteroclitus) from polluted and unpolluted environments. Mar. Environ. Res. 39, 329-333. https://doi.org/10.1016/ 0141-1136(94)00070-6.

Tixier, C. Sancelme, M., Aït-Aïssa, S., Widehem, P., Bonnemoy, F., Cuer, A., Truffaut, N., Veschambre, H., 2002. Biotransformation of phenylurea herbicides by a soil bacterial strain, Arthrobacter sp. N2: structure, ecotoxicity and fate of diuron metabolite with soil fungi. Chemosphere 46, 519-526.

Tomkins, P., Saaristo, M., Allinson, M., Wong, B.B.M., 2016. Exposure to an agricultural contaminant, 17??-trenbolone, impairs female mate choice in a freshwater fish. Aquat. Toxicol. 170, 365-370. https://doi.org/10.1016/ j.aquatox.2015.09.019.

Trainor, B.C., Sisk, C.L., Nelson, R.J., 2017. In: Pfaff et al eds (Ed.), Hormonal Processes in the Development and Expression of Aggressive Behavior. Hormones Brain 
and Behavior., 3rd Ed. https://doi.org/10.1093/acrefore/9780190264086.013.11 Triebskorn, R., Köhler, H.-R., Honnen, W., Schramm, M., Adams, S.M., Müller, E.F. 1997. Induction of heat shock proteins, changes in liver ultrastructure, and alterations of fish behavior: are these biomarkers related and are they useful to reflect the state of pollution in the field? J. Aquat. Ecosyst. Stress Recov. 6, $57-73$.

Turner, G.F., Huntingford, F.A., 1986. A problem for game theory analyses: assessment and intention in male mouth brooder contests. Anim. Behav. 34, 961-970.

Weber, R.A., Pérez Maceira, J.J., Mancebo, M.J., Peleteiro, J.B., García Martín, L.O., Aldegunde, M., 2012. Effects of acute exposure to exogenous ammonia on cerebral monoaminergic neurotransmitters in juvenile Solea senegalensis. Ecotoxicology 21, 362-369. https://doi.org/10.1007/s10646-011-0797-8.

Wendelaar-Bonga, S.E., 1997. The stress response in fish. Physiol. Rev. 77, 591-625. Wingfield, J.C., Hegner, R.E., Dufty, A.M., Ball, G.F., 1990. The “challenge hypothesis": theoretical implications for patterns of testosterone secretion, mating systems, and breeding strategies. Am. Nat. 136, 829-846.

Yu, K.L., Rosenblum, P.M., Peter, R.E., 1991. In vitro release of gonadotropin-releasing hormone from the brain preoptic-anterior hypothalamic region and pituitary of female goldfish. Gen. Comp. Endocrinol. 81, 256-267. 